\title{
Cross-reaction between a strain of Vibrio mimicus and V. cholerae 0139 Bengal
}

\author{
M. ANSARUZZAMAN, T. SHIMADA*, N. A. BHUIYAN, S. NAHAR, K. ALAM, M. S. ISLAM and \\ M. JOHN ALBERT \\ Laboratory Sciences Division, International Centre for Diarrhoeal Disease Research, Bangladesh and \\ * Laboratory of Enteric Infection I, National Institute of Infectious Diseases, 1-23-1 Toyama, Shinjuku-ku, Tokyo \\ 162-8640, Japan
}

\begin{abstract}
Of 200 isolates of Vibrio mimicus screened, one from water (N-57) agglutinated with $V$. cholerae 0139 polyclonal antiserum (absorbed with a rough strain of $V$. cholerae only) and not with 0139 polyclonal diagnostic antiserum (absorbed with the rough strain and $V$. cholerae 022 and 0155 ). The antigenic relationship between $V$. cholerae 0139 and $\mathbf{N}$ 57 is of a,b-a,c type, where $a$ is the common antigenic epitope and $b$ and $c$ are unique epitopes. Strain N-57 was assigned to a new serogroup of $V$. cholerae O194. It gave negative results in a monoclonal antibody-based rapid test and a PCR test specific for $V$. cholerae 0139. It did not possess the ctx gene or produce cholera toxin. Antiserum to strain $\mathrm{N}-57$ cross-protected infant mice against cholera on challenge with $V$. cholerae 0139. Structural studies of the surface polysaccharides and studies of the $\mathrm{rfb}$ genes will shed more light on the extent of relatedness between $V_{0}$ mimicus $\mathrm{N}-57$ and $V$. cholerae 0139.
\end{abstract}

\section{Introduction}

Since the outbreaks of cholera in 1992-1993, Vibrio cholerae 0139 Bengal has become established as a causative agent of endemic cholera in the Indian subcontinent. Genetic studies indicated that $V$. cholerae $\mathrm{O} 139$ is probably a mutant of $V$. cholerae O1 El Tor, and that it might have arisen by substitution of $\mathrm{rfb}$ genes that encode the lipopolysaccharide (LPS) antigen in $V$. cholerae $\mathrm{O} 1$ by genes that encode the LPS antigen and the capsular antigen of $V$. cholerae 0139 [1]. The organism that would potentially donate $\mathrm{rfb}$ genes for surface polysaccharide synthesis in $V$. cholerae $\mathrm{O} 139$ has not been identified. $V$. cholerae $\mathrm{O} 139$ also crossreacts with a number of bacteria, including $V$. cholerae serogroups $\mathrm{O} 22$ and $\mathrm{O} 155$ [2], and Aeromonas trota [3]. In addition, as the core antigen is common to all $V$. cholerae serogroups, $V$. cholerae $\mathrm{O} 139$ also shares this antigen with other $V$. cholerae serogroups [2]. Therefore, for production of specific diagnostic polyclonal antiserum to $V$. cholerae $\mathrm{O} 139$, the antiserum must be absorbed with a rough strain of $V$. cholerae and with $V$.

Received 14 Sept. 1998; revised version received 20 Dec. 1998; accepted 19 Jan. 1999.

Corresponding author: Dr M. J. Albert (e-mail: albert@ icddrb.org). cholerae $\mathrm{O} 22$ and $\mathrm{O} 155$ [2]. A rapid test based on specific monoclonal antibodies (MAbs) to $V$. cholerae O139 has been developed that detects the bacterium directly from the samples [4]. The objectives of a search for bacteria that cross-react with $V$. cholerae $\mathrm{O} 139$ are three-fold: to identify the bacterium that would have donated the $\mathrm{rfb}$ genes for $\mathrm{O} 139$ antigen, to continually ensure the specificity of monoclonal and polyclonal sera to $V$. cholerae $\mathrm{O} 139$ for diagnosis, and to characterise cross-reacting bacteria for general microbiological interest. The continuing search for cross-reacting bacteria identified a water isolate of $V$. mimicus that agglutinated with $V$. cholerae 0139 antiserum. This isolate was characterised with respect to its antigenic and virulence properties.

\section{Materials and methods}

\section{Bacterial strains}

One hundred $V$. mimicus strains isolated from diarrhoeal stools of patients treated at the Dhaka treatment facility of the International Centre for Diarrhoeal Disease Research, Bangladesh (ICDDR,B), during 1968-1993, and 100 strains of $V$. mimicus isolated from surface and well waters in Dhaka and Matlab, Bangladesh, during 1989-1993, were studied. $V$. mimicus was identified by standard methods [5]. 


\section{Production of antisera}

Antisera were produced in adult New Zealand White rabbits against live cells of $V$. cholerae $\mathrm{O} 139$ (strain AI1852), cross-reacting $A$. trota (strain 1354) [3] and cross-reacting $V$. mimicus (strain $\mathrm{N}-57$ ). The preparation of antigen and the immunisation schedule have been described previously [3]. Antibody to core antigen was removed by absorption of antisera with a rough strain of $V$. cholerae (strain CA385) [3]. Antisera to $V$. cholerae $\mathrm{O} 22$ and $\mathrm{O} 155$ were those prepared previously at the National Institute of Health, Tokyo, Japan [2].

\section{Slide agglutination test}

Each of the 200 strains of $V$. mimicus was tested in a slide agglutination test with two antisera to $V$. cholerae O139: antiserum absorbed with the rough $V$. cholerae strain CA385, and diagnostic antiserum absorbed with strain CA385, V. cholerae $\mathrm{O} 22$ and $V$. cholerae $\mathrm{O} 155$ [2]. Strains that gave positive results were further tested for agglutination with antisera to $V$. cholerae $\mathrm{O} 22$ and $\mathrm{O} 155$, and A. trota strain 1354, and with two mouse MAbs (ICL11 and ICL12) specific for $V$. cholerae O139, as described previously [6].

\section{Tube agglutination test}

The tube agglutination test was performed as described previously. Doubling dilutions of antisera were tested from a starting dilution of 1 in 20. Agglutination was scored on a 0 to $4+$ scale, and the endpoint titre was defined as the highest dilution of antiserum yielding a $2+$ agglutination of cells [3].

\section{Agglutinin-absorption test}

After incubation of antigen-antibody mixture, the supernate was filter-sterilised. Antisera were absorbed either with a single culture or multiple cultures as required [3].

\section{Serogrouping}

The cross-reacting V. mimicus strain was subjected to $O$ serogrouping with antisera to the 155 serogroups of $V$. cholerae previously recognised [2] and to 38 other serogroups (serogroups O156-O193) recognised subsequently (unpublished data). $V$. cholerae and $V$. mimicus have a common serogrouping scheme.

\section{Studies with LPS antigens}

LPS was extracted by the hot phenol-water extraction method, separated on SDS-polyacrylamide $13.5 \%$ gels and visualised by silver staining. For immunoblotting, the separated LPS was probed with rabbit polyclonal antiserum to the relevant bacteria, and then with alkaline phosphatase-conjugated swine anti-rabbit $\mathrm{IgG}$ [3].

\section{Bengal SMART test}

The Bengal SMART test, which is a rapid test for $V$. cholerae $\mathrm{O} 139$, is a colorimetric immunoassay that uses the colloidal gold-labelled MAb ICL12 to $V$. cholerae O139 [4]. The ability of the SMART test to detect cross-reacting $V$. mimicus was tested according to the manufacturer's instructions.

\section{PCR assay for $V$. cholerae 0139 antigen}

The cross-reacting $V$. mimicus was tested in a PCR assay with primers specific for the $\mathrm{O}$-antigen of $V$. cholerae $\mathrm{O} 139$ as described previously [7].

\section{Enterotoxin production}

Culture filtrate was tested in mouse Y1 adrenal tumour cells for cholera toxin-like enterotoxin and in the suckling mouse assay for heat-stable enterotoxin [3]. The criterion for a positive test in the $\mathrm{Y} 1$ cell assay was rounding of $>50 \%$ of the cell monolayer, and that for the suckling mouse assay was a ratio of $>0.085$ for intestinal body weight to remaining body weight from five mice per test [3].

The cross-reacting $V$. mimicus strain was also tested in a PCR assay for cholera toxin gene (ctx) with two primers corresponding to the ctx operon of $V$. cholerae $\mathrm{O} 1$ as described previously [8].

\section{Passive protection in infant mouse cholera model}

To study the protective efficacy of polyclonal antiserum to the cross-reacting $V$. mimicus, $0.1 \mathrm{ml}$ of a 1 in 10 diluted antiserum in physiological saline was mixed with a 100 LD50 dose of a clinical isolate of $V$. cholerae $\mathrm{O} 139$ (strain $\mathrm{AI}-1852$ ) and injected into a group of 4-day-old mice. Mortality was observed for up to $48 \mathrm{~h}[9]$.

\section{Results and discussion}

Of $200 \mathrm{~V}$. mimicus strains tested, only one strain, isolated from pond water, agglutinated with $V$. cholerae O139 polyclonal antiserum (absorbed only with $V$. cholerae CA385) in a slide agglutination test. However, this strain did not agglutinate with the $V$. cholerae O139 diagnostic antiserum (absorbed with CA385, and $V$. cholerae $\mathrm{O} 22$ and $\mathrm{O} 155$ ). It also agglutinated with antisera to $V$. cholerae $\mathrm{O} 22$ and cross-reacting $A$. trota (strain 1354), but not with antiserum to $V$. cholerae 0155. The strain was designated N-57.

The results of agglutination and agglutinin-absorption tests are shown in Table 1. Cross-absorption of antisera to $V$. cholerae $\mathrm{O} 139$ and $V$. mimicus with heterologous bacteria of $V$. mimicus and $V$. cholerae 0139 caused reductions in antibody titres to the homologous bacteria. Such reductions in homologous titres occurred when antisera to $V$. cholerae $\mathrm{O} 22$ and $A$. trota were 
Table 1. Agglutination and agglutinin-absorption tests with antisera to V. mimicus (N-57), V. cholerae O139 (AI-1852), V. cholerae $\mathrm{O} 22, V$. cholerae $\mathrm{O} 155$ and $A$. trota (1354)

\begin{tabular}{|c|c|c|c|c|c|c|}
\hline \multirow[b]{2}{*}{ Antiserum* } & \multirow[b]{2}{*}{$\begin{array}{l}\text { Absorbing } \\
\text { organism }^{\dagger}\end{array}$} & \multicolumn{5}{|c|}{ Titre of antisera to $O$ antigens from } \\
\hline & & $\begin{array}{l}\text { V. mimicus } \\
(\mathrm{N}-57)\end{array}$ & $\begin{array}{c}V . \text { cholerae } \\
\text { O139 (AI-1852) }\end{array}$ & $\begin{array}{c}\text { V. cholerae } \\
\mathrm{O} 22\end{array}$ & $\begin{array}{l}\text { V. cholerae } \\
0155\end{array}$ & $\begin{array}{l}\text { A. trota } \\
(1354)\end{array}$ \\
\hline V. mimicus $(\mathrm{N}-57)$ & $\begin{array}{l}\text { None } \\
\text { V. cholerae } \mathrm{O} 139 \\
V . \text { cholerae } \mathrm{O} 22 \\
\text { A. trota }\end{array}$ & $\begin{array}{r}2560 \\
640 \\
1280 \\
640\end{array}$ & $\begin{array}{c}160 \\
- \\
40 \\
40\end{array}$ & $\begin{array}{l}40 \\
- \\
- \\
20\end{array}$ & $\begin{array}{l}-\ddagger \\
- \\
- \\
-\end{array}$ & $\begin{array}{l}80 \\
- \\
- \\
-\end{array}$ \\
\hline V. cholerae $\mathrm{O} 139$ (AI-1852) & $\begin{array}{l}\text { None } \\
V \text { mimicus }\end{array}$ & $\begin{array}{c}320 \\
-\end{array}$ & $\begin{array}{r}1280 \\
640\end{array}$ & $\begin{array}{l}640 \\
640\end{array}$ & $\begin{array}{l}40 \\
40\end{array}$ & $\begin{array}{l}640 \\
640\end{array}$ \\
\hline V. cholerae $\mathrm{O} 22$ & $\begin{array}{l}\text { None } \\
V \text {. mimicus }\end{array}$ & $\begin{array}{l}160 \\
-\end{array}$ & $\begin{array}{l}320 \\
160\end{array}$ & $\begin{array}{l}640 \\
320\end{array}$ & $\begin{array}{l}- \\
-\end{array}$ & $\begin{array}{l}640 \\
640\end{array}$ \\
\hline V. cholerae 0155 & $\begin{array}{l}\text { None } \\
V \text {. mimicus }\end{array}$ & - & $\begin{array}{l}80 \\
80\end{array}$ & - & $\begin{array}{l}640 \\
640\end{array}$ & - \\
\hline A. trota (1354) & $\begin{array}{l}\text { None } \\
\text { V. mimicus }\end{array}$ & $\begin{array}{c}320 \\
-\end{array}$ & $\begin{array}{r}1280 \\
320\end{array}$ & $\begin{array}{r}160 \\
40\end{array}$ & $\begin{array}{l}- \\
-\end{array}$ & $\begin{array}{l}2560 \\
1280\end{array}$ \\
\hline
\end{tabular}

* Antibody to core antigen in these sera was absorbed with a rough strain of $V$, cholerae (CA385).

${ }^{\dagger}$ Absorbed with live and boiled organisms; boiled $\left(100^{\circ} \mathrm{C}\right.$ for $\left.1 \mathrm{~h}\right)$ cultures were used.

${ }^{\ddagger}$ No agglutination at a dilution of 1 in $\geqslant 20$.

absorbed with $V$. mimicus. These data suggested that the antigenic relationship between $V$. mimicus $\mathrm{N}-57$ and $V$. cholerae $0139, V$. cholerae $\mathrm{O} 22$ and $A$. trota is that of $a, b-a, c$ type where $a$ is the common epitope and $b$ and $c$ are unique epitopes. This is because absorption of an antiserum with a heterologous strain failed to remove antibodies to the homologous strain completely. This type of antigenic relationship has been shown previously between $V$. cholerae $\mathrm{O} 139$ and other crossreacting bacteria such as $V$. cholerae $\mathrm{O} 22$ and 0155 and $A$. trota $[2,3]$. Consistent with the slide agglutination test, $V$. mimicus did not agglutinate with $V$. cholerae $\mathrm{O} 155$ antiserum. $V$. cholerae $\mathrm{O} 155$ also did not agglutinate with $V$. mimicus antiserum. Different patterns of reactions were observed among $V$. cholerae O139, $\mathrm{O} 22$ and $\mathrm{O} 155$ and $A$. trota when antisera to these organisms were absorbed with $V$. mimicus.

The SDS-PAGE separation profile of LPS from $V$. mimicus $\mathrm{N}-57$ and $V$. cholerae $0139 \mathrm{AI}-1852$ is shown in Fig. 1. The profile of $V$. mimicus resembled that of smooth bacteria revealing a core antigen (thick band at the bottom of the gel) and an O-antigenic repeating polysaccharide (ladder-like portion in the top part of the gel). However, the LPS pattern of $V$. cholerae 0139 resembled that of semi-rough bacteria as reported earlier [1] revealing a modified core structure and no high mol. wt $\mathrm{O}$ antigen-specific side chain. Immunoblot studies with antisera to $V$. cholerae 0139 and $V$. mimicus recognised homologous and heterologous LPS antigens equally well. In Fig. 2, the immunoblots are shown with antiserum to $V$. mimicus only. Compared with the LPS pattern in Fig. 1, the core antigens in the bottom portion of the gel in Fig. 2 are not stained because the core antibody has been absorbed out. These studies further confirmed the antigenic relationship between $V$. cholerae $\mathrm{O} 139$ and $V$. mimicus $\mathrm{N}-57$.

The LD50 of the challenge strain of $V$. cholerae O139,

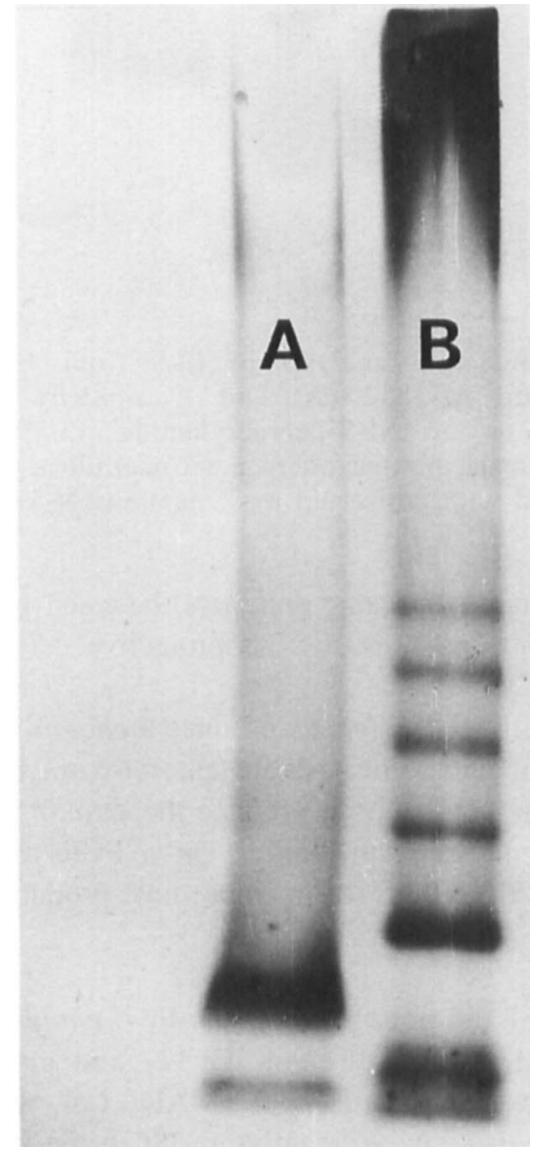

Fig. 1. LPS profile of $V$. cholerae O139 strain AI-1852 (A) and $V$. mimicus N-57 (B). The LPS preparations were electrophoresed on an SDS-polyacrylamide $13.5 \%$ gel and were silver stained.

AI-1852, for infant mice was $10^{3} \mathrm{cfu}$ in $0.1 \mathrm{ml}$ of inoculum. A 1 in 10 dilution of polyclonal antiserum to isolate N-57 completely protected mice against a challenge dose of 100 LD50 of strain AI-1852. However, all the mice died when a 1 in 10 dilution of pre-immune rabbit serum was used. This suggested 


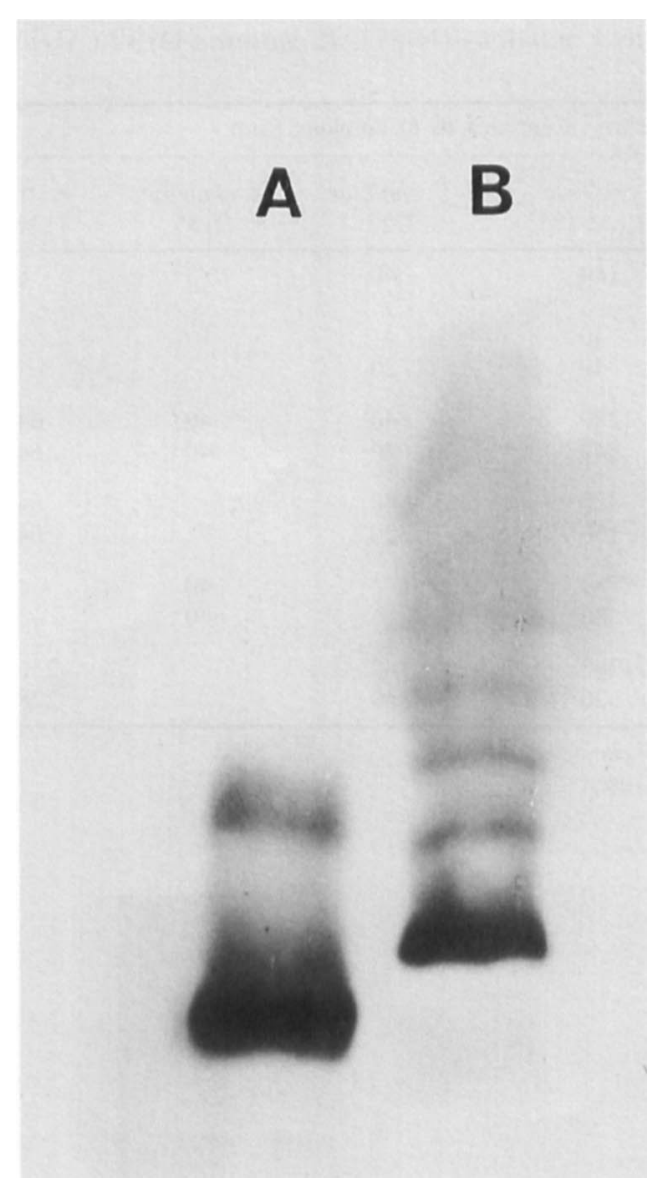

Fig. 2. Immunoblot analysis of LPS from $V$. cholerae 0139 strain AI-1852 (A) and $V$. mimicus $\mathrm{N}-57$ (B) separated on an SDS-polyacrylamide $13.5 \%$ gel by electrophoresis, blotted on to a nitrocellulose membrane and probed with antiserum to $V$. mimicus $\mathrm{N}-57$.

that the shared antigenic epitope(s) between $V$. cholerae $\mathrm{O} 139$ and $V$. mimicus $\mathrm{N}-57$ is protective.

Some strains of $V$. mimicus produce a cholera toxin-like enterotoxin and a heat-stable enterotoxin [10]. However, strain N-57 did not produce these toxins, and also gave a negative result for ctx in a PCR assay. This indicated that this strain may not produce watery diarrhoea.

Strain N-57 did not agglutinate with $V$. cholerae O139specific MAbs (ICL11 and ICL12) and also gave a negative result in the Bengal SMART test, which uses ICL12. It also gave a negative result in the PCR assay specific for $V$. cholerae $\mathrm{O} 139$ as it failed to generate an amplicon of $416 \mathrm{bp}$ [7]. These data suggest that such cross-reacting $V$. mimicus strains will not be misdiagnosed as $V$. cholerae 0139 . The cross-reacting $V$. mimicus strain, $\mathrm{N}-57$, could not be serogrouped with antisera to the $193 \mathrm{O}$ serogroups of $V$. cholerae. Therefore, a new serogroup, O194, was assigned to this strain.

Structural analysis of surface polysaccharide of $V$. cholerae 0139 suggested that it contains two unique constituents, galactose cyclophosphate and colitose [11]. Some cross-reacting bacteria share either or both of these structures $[12,13]$. A previous study found that the cross-reacting between $V$. mimicus strain $\mathrm{N}$ 1990 and $V$. cholerae $\mathrm{O} 139$ is due to sharing of the galactosyl residue substituted with a cyclic phosphate by both bacteria [14]. The structural basis of crossreaction as well as the homology of the $\mathrm{rfb}$ genes encoding the surface polysaccharides in both $V$. cholerae 0139 and strain $\mathrm{N}-57$ will need to be determined to further explore the relatedness between these two bacteria.

Worldwide efforts are being made to contain the threat of 'emerging and re-emerging pathogens'. $V$. cholerae $\mathrm{O} 139$ is a newly emerged pathogen, and is considered to be the causative agent of the 'eighth' pandemic of cholera. The potential of cross-reacting bacteria for use as vaccine strains against $\mathrm{O} 139$ cholera should also be explored.

This research was supported by the Swedish Agency for Research Cooperation with Developing Countries (grant INT-ICDDR,B-HN-01AV) and the ICDDR,B Centre for Health and Population Research. The Centre is supported by agencies and countries that share its concern for the health and population problems of developing countries. We thank Mr Shipan K. Sarker for secretarial assistance.

\section{References}

1. Stroeher UH, Jedani KE, Dredge BK et al. Genetic rearrangements in the $\mathrm{rfb}$ regions of Vibrio cholerae $\mathrm{O} 1$ and 0139 . Proc Natl Acad Sci USA 1995; 92: 10374-10378.

2. Shimada T, Arakawa E, Itoh K, Nakazato T. Two strains of Vibrio cholerae non-O1 possessing somatic $(\mathrm{O})$ antigen factors in common with $V$. cholerae serogroup 0139 synonym 'Bengal'. Curr Microbiol 1994; 29: 331-333.

3. Albert MJ, Ansaruzzaman M, Shimada $\mathrm{T}$ et al. Characterization of Aeromonas trota strains that cross-react with Vibrio cholerae O139 Bengal. J Clin Microbiol 1995; 33: 3119-3123.

4. Qadri F, Hasan JAK, Hossain $\mathrm{J}$ et al. Evaluation of the monoclonal antibody-based kit Bengal SMART for rapid detection of Vibrio cholerae O139 synonym Bengal in stool samples. J Clin Microbiol 1995; 33: 732-734.

5. McLaughlin JC. Vibrio. In: Murray PR, Baron EJ, Pfaller MA, Tenover FC, Yolken RH (eds) Manual of clinical microbiology, 6th edn. Washington, DC, ASM Press. 1995: 465-476.

6. Qadri F, Azim T, Chowdhury A, Hossain J, Sack RB, Albert MJ. Production, characterization, and application of monoclonal antibodies to Vibrio cholerae O139 synonym Bengal. Clin Diagn Lab Immunol 1994; 1: 51-54.

7. Albert MJ, Islam D, Nahar S, Qadri F, Falklind S, Weintraub A. Rapid detection of Vibrio cholerae O139 Bengal from stool specimens by PCR. J Clin Microbiol 1997; 35: 1633-1635.

8. Shirai H, Nishibuchi M, Ramamurthy T, Bhattacharya SK, Pal $\mathrm{SC}$, Takeda Y. Polymerase chain reaction for detection of the cholera enterotoxin operon of Vibrio cholerae. J Clin Microbiol 1991; 29: 2517-2521.

9. Attridge SR, Rowley D. The role of flagellum in the adherence of Vibrio cholerae. $J$ Infect Dis 1983; 147: 864-872.

10. Davis BR, Fanning GR, Madden JM et al. Characterization of biochemically atypical Vibrio cholerae strains and designation of a new pathogenic species, Vibrio mimicus. J Clin Microbiol 1981; 14: 631-639.

11. Knirel YA, Paredes L, Jansson P-E, Weintraub A, Widmalm G, Albert MJ. Structure of the capsular polysaccharide of Vibrio cholerae O139 synonym Bengal containing D-galactose-4,6cyclophosphate. Eur J Biochem 1995; 232; 391-396.

12. Knirel YA, Senchenkova SN, Jansson P-E, Weintraub A, Ansaruzzaman M, Albert MJ. Structure of the O-specific polysaccharide of an Aeromonas trota strain cross-reactive with 
Vibrio cholerae 0139 Bengal. Eur J Biochem 1996; 238: 160165.

13. Senchenkova SN, Zatonsky GV, Shashkov AS et al. Structure of the O-antigen of Vibrio cholerae $\mathrm{O} 155$ that shares a Dgalactose-4,6-cyclophosphate-associated epitope with $V$. choler- ae O139 Bengal. Eur $J$ Biochem 1998; 254: 58-62.

14. Landersjo C, Weintraub A, Ansaruzzaman M, Albert MJ, Widmalm G. Structural analysis of the O-antigenic polysaccharide from Vibrio mimicus N-1990. Eur J Biochem 1998; 251: $986-990$. 